Article

\title{
Sustainable Business Models for Informal Charcoal Producers in Kenya
}

\author{
Doris Mutta $^{1}$, Larwanou Mahamane ${ }^{2}$, Chemuku Wekesa ${ }^{3} \mathbb{D}$, Godwin Kowero ${ }^{1}$ and Anders Roos ${ }^{4, *}$ \\ 1 African Forest Forum, 00100 Nairobi, Kenya; d.mutta@cgiar.org (D.M.); g.kowero@cgiar.org (G.K.) \\ 2 International Crops Research Institute for the Semi-Arid Tropics, 8001 Niamey, Niger; \\ m.larwanou@gmail.com \\ 3 Taita Taveta Sub-Regional Research Centre, Kenya Forestry Research Institute, 80304 Wundanyi, Kenya; \\ chemukukefri@gmail.com \\ 4 Department of Forest Economics, Swedish University of Agricultural Sciences, SE-750 07 Uppsala, Sweden \\ * Correspondence: anders.roos@slu.se
}

Citation: Mutta, D.; Mahamane, L.; Wekesa, C.; Kowero, G.; Roos, A. Sustainable Business Models for Informal Charcoal Producers in Kenya. Sustainability 2021, 13, 3475. https://doi.org/10.3390/su13063475

Academic Editor: Richard Blanchard

Received: 13 February 2021

Accepted: 16 March 2021

Published: 21 March 2021

Publisher's Note: MDPI stays neutral with regard to jurisdictional claims in published maps and institutional affiliations.

Copyright: (c) 2021 by the authors. Licensee MDPI, Basel, Switzerland. This article is an open access article distributed under the terms and conditions of the Creative Commons Attribution (CC BY) license (https:/ / creativecommons.org/licenses/by/ $4.0 /)$.

\begin{abstract}
The sustainable business model (SBM) concept requires enterprises to integrate sustainability aspects in their planning and operations. Although $60 \%$ of the global working population make their living in the informal sector mostly in low-and middle income countries, the potential for SBMs has rarely been analyzed for this category. This study explores the SBMs of informal charcoal-producing enterprises in coastal Kenya. It describes key business-model components: value proposition, value creation and delivery, and economic value capture. Impact and dependency on sustainability-related indicators were also studied. Data were obtained through individual interviews, focus-group discussions, and workshops for charcoal producers and other relevant stakeholders. Findings demonstrated that charcoal enterprises, despite their informal status, adopt elaborate business models. The incomes positively affect several Sustainable Development Goals (SDGs) by reducing, if not eradicating, poverty and supporting basic livelihood needs. Examples of negative impacts on some SDG include the activity's contribution to forest degradation. Feedback impacts, where SDG status influence the informal enterprises' opportunities were also identified. The SBM model contributes to the development of a balanced sustainability transition of the charcoal sector. We suggest further analyses of the role of informal enterprises in the bioenergy sector for sustainable development and how their SBMs could be improved.
\end{abstract}

Keywords: bioenergy; business strategy; green business; livelihoods; value chain

\section{Introduction}

Charcoal is an essential and affordable energy source for many households in Africa. Approximately $90 \%$ of the annual wood harvest in Africa is used for energy, out of this volume, $20 \%$ is processed into charcoal [1,2]. Driven by population growth and urbanization, production is increasing $[2,3]$.

In Africa, charcoal plays a significant two-sided role in the attainment of the Sustainable Development Goals (SDGs) by 2030 [4]. It provides livelihoods to hundreds of thousands of persons through informal, often family-based, enterprises [5] (p. 23), [6]. On the other hand, charcoal production can cause forest degradation and biodiversity loss [5-7]. Sustainability indicators, related to society's human capital, institutions, or natural resources, can simultaneously through different feedback impacts, affect the sector's business opportunities [8,9]. Charcoal business is becoming a concern for governments that have to weigh a range of policy goals related to climate, biodiversity conservation, and poverty reduction. The success rates of different policy interventions to date have been mixed [1].

This analysis focuses on the business models for informal charcoal-producing enterprises in Africa, and the potential to make them sustainable. Aspects of African charcoal en- 
terprises have been studied over recent decades with regard to poverty perspective [10-12], policies and regulations [13], and impacts on community-level benefits [14,15]. Studies have also partly covered business strategies and the economic performance of charcoal enterprises [11,12]. Together, studies characterize charcoal producers as low-investment enterprises with modest profits that are used for poverty reduction and the provision of basic human needs. Production is generally in some cases based on unsustainable forest management practices with adverse environmental impacts.

There is a need for actor-centered studies of how business models can promote a sustainability transition for the informal charcoal sector that reduces adverse sustainability impacts and increases positive impacts $[1,16]$. Sustainable Business Models (SBMs) can provide a holistic understanding of how an enterprise's value creation and value capture have an impact on sustainability criteria; hence, they are useful for explorations of pathways to design more truly sustainable business practices $[17,18]$. Although new knowledge on sustainable businesses is continuously being developed [1], the concept has more frequently focused on formal than informal enterprises such as charcoal producers in Africa.

There are several reasons to intensify the study of business models and SBMs for informal charcoal enterprises in Africa. First, the charcoal sector in Africa features several, both beneficial and adverse, impacts on sustainability that assumedly constitute dilemmas or "wicked" problems for producers and policymakers. Secondly, Africa faces serious challenges in achieving several SDGs, for example, with regard to poverty, hunger, or employment [19], and has the highest deforestation rates in the world [20]. The continent consequently needs to speed up its sustainability transition, which requires knowledge that can support this change. Thirdly, the study of SBMs in the informal sector is relevant because the sector employs about $60 \%$ of the global working population, a share that is even higher in Africa and especially in its rural areas [21]. Business models in informal enterprises have been studied [12,22]. However, the applications of this framework in the bioenergy field remain scanty; much as the role of the charcoal industry is important in terms of, number of producers and consumers and its role in rural economies, share in national energy balances, used wood volume, and share of global charcoal production [1]. In this regard, the sector has a key role to play in achieving some of the SDGs.

Although challenges associated with the charcoal sector have several dimensions that call for a range of new insights, the SBM framework could to some degree contribute towards the process by (1) improving insights about current business practices in the sector; (2) supporting charcoal enterprises, policymakers, and stakeholders to evaluate ways towards sustainability improvements; and (3) enabling a constructive dialogue among stakeholders that incorporate businesses, livelihoods, and sustainability outcomes. In turn, more accurate knowledge about the operations and business conditions from the actors perspective and the uptake of policy measures could lead to more effective policies with regard to charcoal in earnest of sustainable development.

This study described and analyzed SBMs for charcoal-producing enterprises in Kenya, characterized components of the business models, and identified associations between business models and sustainability indicators. The underlying intention was to contribute to a balanced sustainability transition in the sector [23]. The specific objectives for this study were to:

- Document and analyze informal charcoal producers' business models concerning value-proposition, creation, and capture.

- Assess positive and negative impacts that the business model is creating for the environment and/or society; and the corresponding feedback impacts that the sustainability status have on the charcoal enterprise.

The unit of analysis for this study was the business model in the sector and its extension to a SBM. Thus, this study focused on typical practices, and not statistical averages and distributions of producers. Analysis and calculations were related to a normal, full-time, charcoal-producing enterprise. 
The following section develops the conceptual SBM for this study, followed by a description of the study area and the methods employed. The results section applies the SBM to typical charcoal enterprises in Kenya. Furthermore, the section presents economic outcomes and scenarios to illustrate the economic impact of the strategy choices. The discussion section brings up the implications and limitations of the findings. The paper ends with concluding remarks.

\section{Materials and Methods}

\subsection{Conceptual Framework}

The study was partly based on the business model concept, which is a common tool for reviewing a business' ability to create value [24]. Additionally, a SBM incorporates social, economic, and environmental impacts into the business processes. "A sustainable business model is about creating significantly increased positive effects and/or significantly reduced negative effects on the natural environment and society through changes in the way a company and its network create, deliver, and capture value" [18] (p. 147). The concept is increasingly being promoted to enhance the co-creation of business and sustainability benefits $[18,25,26]$. Sustainability can be based on different definitions [17]; in this study, it refers to the UN Sustainability Agenda [4]. The business community's central role in the achievement of the SDGs was recognized in the UN resolution text on the SDGs [4] (Article 67). Finally, our framework considers feedback impacts where the status of SDGs - such as the natural environment or for human capital-influence the business opportunities [9].

The conceptual SBM model for this study features the business model canvas, which is based on the value proposition, value creation and delivery, and economic value capture. Furthermore, it includes sustainability impacts from the business activities on society and the natural environment [18] and sustainability feedback which describe how sustainability indicators, or SDG status, influence charcoal enterprises' performance [4,9] (Figure 1).

\section{Business model canvas}

Value proposition: (products and services, customer segments and relationships)

Value creation and delivery (key activities, partnerships, resources, and channels)

Economic value capture (cost structure and revenue streams)

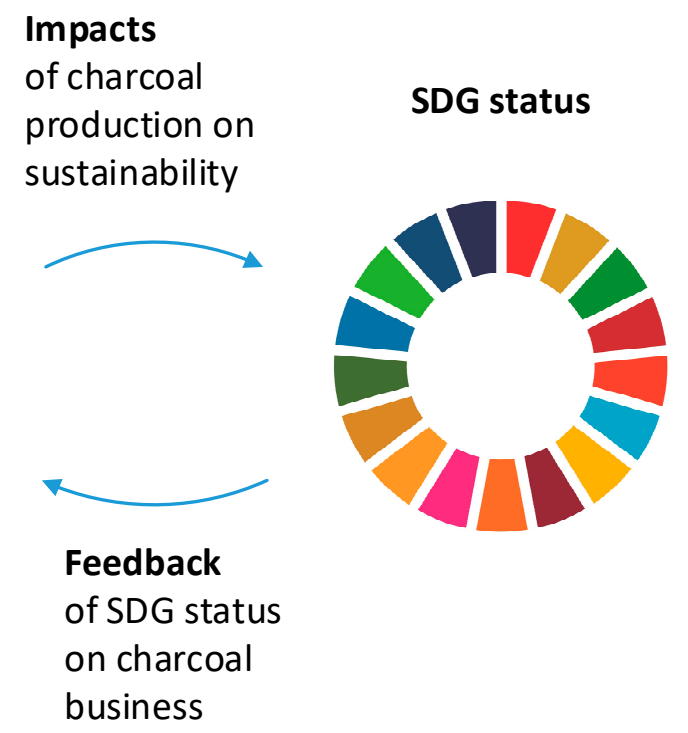

Figure 1. Conceptual SBM.

\subsection{The Study Region} (Table 1).

This study was conducted in the Taita Taveta and Kwale counties in coastal Kenya

Table 1. Overview of Taita Taveta and Kwale Counties $[27,28]$.

\begin{tabular}{lrrr}
\hline County & Area $\left.\mathbf{( k m}^{\mathbf{2}}\right)$ & Population & Forest Area $\mathbf{( k m}^{\mathbf{2}} \mathbf{)}$ \\
\hline Taita Taveta & 17,100 & 341,000 & 620 \\
Kwale & 8300 & 867,000 & 450 \\
\hline
\end{tabular}


Taita Taveta County has moderate charcoal production, where National Parks are exempted from all farming and forestry-related activities. Larger charcoal quantities are produced in Kwale County, adjacent to Mombasa City, which is a key market for charcoal (1.2 million inhabitants). Charcoal is used by $11 \%$ and $30 \%$ of the households in Kwale and Mombasa counties respectively (Figures for Taita Taveta were not available) [27,29]. Charcoal accounts for $17 \%$ of the household energy consumption in Kenya, with the largest share being in urban areas [30].

A charcoal ban, imposed in Kenya in February 2018, has affected trade and undermined the role of the village-based Charcoal Producer Associations (CPAs) [31]. CPAs, were, before the ban, responsible for sustainable charcoal production that did not degrade the forest cover and coordinated reforestation activities and development of conservation plans for sustainable charcoal production. Consumption is not forbidden and hence considerable charcoal production and use still continues even after the ban in 2018 [32]. Since charcoal production and trade is informal and partly banned, precise production or consumption figures are not easily available.

\subsection{Research Approach}

An exploratory approach was selected to gain an insight into the various business practices and business models' properties. The study used qualitative methods and an actor-centered perspective, where producers were mostly viewed as strategic entrepreneurs who evaluate and choose strategies according to expected outcomes [33-36].

This was followed by participatory analysis approaches that included dialogues with, and collating information from the local communities. The approach captured producers' perceptions, reflections, and plans to improve their activity and it contained open discussions and follow-up questions with the local communities [35,37]. Ethical guidelines set by the International Society of Ethnobiology (ISE) guided the research, for example, regarding prior informed consent, confidentiality, respect, supporting indigenous research, and dynamic interactive cycle [38].

\subsection{Data Collection}

Data were collected in qualitative interviews, focus group discussions (FGDs) involving 4-10 participants categorized by age groups and gender, and followed with workshops with different stakeholders lasting for one day (Table 2) [33,35]. Contacts with producers were facilitated by CPAs.

Table 2. Data collection.

\begin{tabular}{lll}
\hline June 2018. & Respondents & Interview Lengths \\
Data-Collection Type & 43 Producers (21 women, 22 men) & $2 \mathrm{~h}$ \\
\hline Individual interviews & 8 FGDs, mixed and separated on gender and age & $2 \mathrm{~h}$ \\
$\begin{array}{l}\text { Focus-group discussions (FGDs) } \\
\text { Key informant interviews }\end{array}$ & $\begin{array}{l}\text { 8 Key informants representing environmental } \\
\text { non-governmental organizations, county governments, }\end{array}$ \\
& $\begin{array}{l}\text { Kenyan Forest Service, forest-owner associations } \\
\text { Two meetings with stakeholders; } 30 \text { participants in Taita }\end{array}$ & One day \\
Workshops & Taveta and 25 in Kwale. Participants included & \\
& producers, transporters, vendors, public agencies, & \\
& non-governmental organizations & \\
\hline June 2019 & & Interview Lengths \\
Data-Collection Type & Respondents & $2 \mathrm{~h}$ \\
\hline Focus-group discussions & 11 Verification sessions with CPAs & One day \\
Workshops & Two meetings with stakeholders, with 37 participants in & \\
& Taita Taveta and 22 in Kwale. Participants included & \\
& producers, transporters, vendors, public agencies, NGOs & \\
\hline
\end{tabular}


Data were collected in June 2018 with a follow-up visit in June 2019 to present the preliminary research findings and verify the results with the communities and other stakeholders in the charcoal business.

Questionnaires and interview guides covered the producers' business models, that is, value proposition, creation, and delivery; costs; and revenue streams. They also queried livelihood and sustainability impacts from charcoal production, and how the business was affected by policies and external development. Further, interview questions elicited producers' strategies, views, and perceptions on charcoal business operations and sustainability connections. While individual interviews elicited producers' operations, views, and plans, FGDs permitted a dialogue among participants.

Questionnaires were developed through iterative revisions and pretested in the field to ensure reliability. Six enumerators with good connections with local people and fluent in Kiswahili (common language in the area) were recruited and trained in data collection for two days. They had a minimal qualification of a college diploma in either social sciences or community development. Enumerator teams were gender-balanced as provided by the Constitution of Kenya, with one-third being women. Interviews were conducted in Kiswahili, and answers were transcribed in English.

\subsection{Analysis}

Data were transcribed and analyzed through qualitative iterative procedures including coding and noting of narratives [33-35]. Responses were compared and analyzed using the theoretical framework (Figure 1) to outline the business model and sustainability linkages. Economic calculations were conducted to determine economic value capture [39]. All this was to ensure that empirical applications of the business models provide strategic configurations that also constitute narratives for how the business is conducted.

\section{Results}

\subsection{Description of a Typical Charcoal Producer}

Charcoal producers are informal own-account enterprises. The normal production for a full-time charcoal enterprise amounts to approximately 33 runs of seven bags per year, totaling 231 bags of charcoal annually, each bag weighing about $40 \mathrm{~kg}$ (Table 3). However, kiln size and the number of runs per year vary between producers (Examples of individual enterprises are shown in Appendix A).

Table 3. Typical Charcoal Producer, Description.

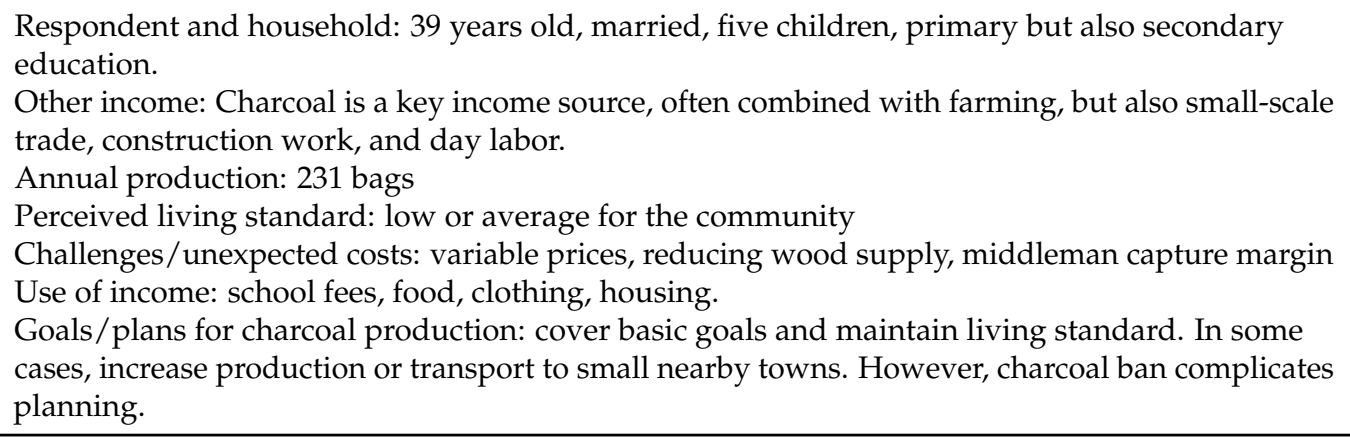

About $90 \%$ of the producers reported that charcoaling is a key source of income, often combined with farming or other economic activities. One-quarter of charcoal producers perceived themselves as below average income earners in the community, while the majority reported that their living standard was at the same level as that of the average villager. The dominating goals for the charcoal business were to earn adequate income to cover basic needs and improve their living standard, rather than, for instance, social motives. Some enterprises had ambitions to increase their production by increasing the number and size of kilns: "to be able to supply 30 bags in a week to get more income" (male producer, 
Taita Taveta), "large-scale: start another kiln at another farm to increase income" (female producer, Kwale); or to access new geographical markets: "expand to new markets in Mombasa to get better prices" (male producer, Kwale).

\subsection{Sustainable Business Model}

\subsubsection{Value Propositions}

Product and Services

The key value proposition encompasses the product (charcoal) and the associated services that are offered to customer segments (Figure 2). High quality charcoal are described as heavy, dark, and shiny, in large pieces, and preferably coming from indigenous tree species. The charcoal should not be overburnt, wet, or contain charcoal powder. Furthermore, the product should be packaged correctly and free from impurities/foreign material such as unburnt wood pieces and stones. Quality problems and associated price reductions were frequently reported, emphasizing the importance of charcoal quality to firm performance. Buyers reportedly appreciated reasonable and stable prices, (although high quality can generate a premium price). They expected some room for bargaining. Service-quality dimensions involve good access to the location of sale and good business relations based on trustworthiness and politeness.

\begin{tabular}{|l|}
\hline Products and services \\
Quality charcoal from indigenous species \\
Dry, no powder, clean \\
Well-packaged \\
Sale location \\
Communication with the customer \\
Trustworthiness and politeness \\
Customer segments \\
Households \\
Small restaurants \\
Middlemen and transporters \\
Customer relations \\
Producers sell both to stable customers and on spot markets \\
Good quality creates customer loyalty \\
Mistrust may occur, for example due to payment default
\end{tabular}

Figure 2. Value proposition.

\section{Customer Segments and Relations}

The direct buyers from producers were intermediaries who transport the charcoal or take care of both the transport and wholesale of produced charcoal. Downstream end customer segments consisted of households, small restaurants, and other businesses like fish sellers that smoke and sell fish on the streets of urban centers.

Producers sell to both stable, loyal customers, and on-spot markets. The degree of customer loyalty mainly depends on the quality of the value proposition, and it was confirmed that good customer relations are important for business success. Mistrust may also occur when producers consider themselves to be exploited by intermediaries, or due to default in payment. 


\subsubsection{Value Creation and Delivery}

Key Activities

Value creation and delivery encompass activities, resources, partnerships, and channels used to meet customer needs and accrue revenue (Figure 3). Key activities in charcoal production are planning - identifying locations and trees for charcoal production, requesting for the landowner's consent to harvest, and preparing tools and equipment; harvestingtree felling and preparation of two-meter pieces of wood for charcoaling, and letting the wood dry for two weeks; carbonization - setting up the kiln for charcoal production, placing and assembling wood pieces, covering the kiln with soil and grass, placing stones around it, initiating and monitoring the carbonization process, and cooling; and lastly packaging and sale-removing the charcoal from the kiln, placing it in bags, and contacting buyer transporters/buyers for sale and delivery.

Activities
Planning
Carvest
Packaging and sale
Resources
Wood, primary local species
Sand, grass
Hand tools
Gunny bags
Charcoaling skills
Calculation skills
Reading and writing skills
Partners
CPAs
Transporters
Customers
County governments
Forest service
Non-governmental organizations (NGOs) such as Wildlife Works

Figure 3. Value creation and delivery.

The adoption of improved processes is slow in the sector, and simple earth kilns are used for charcoaling. However, mobile phones are currently used widely for communication and calculations.

Sale of charcoal normally occurs at the production site, although alternative locations include at the roadside, at home, or in the village. The charcoal ban of 2018 forced most sales to be conducted discreetly, and CPA-managed collection centers in villages are no longer used due to fear of charcoal confiscation.

\section{Resources}

Principal input factors are wood, worktime, and basic tools. Suitable tree species are primarily indigenous species, with Combretum hereroense, Grewia tembensis, Diospyros mespiliformis, and Acacia mellifera being the most preferred. Where required, compensation (approximately USD $1 / \mathrm{bag}$ ) is paid to the landowner for provision of raw material for charcoal production. In other cases, the charcoal producer has free access to the raw materials: "We belong to an association; therefore, we can access the wood using the name of the association" (female producer, Taita Taveta); "We use those people in the ranch to cut the trees for us, then buy from them" (male producer, Kwale). Land ownership 
includes ranch trust land/community land (44\%), own land (46\%), private forests (12\%), and government land $(10 \%)$. The distance from home to the production sites varies, with an average range being $3-4 \mathrm{~km}$.

Hand tools are purchased at a moderate cost and last for 3-5 years. Typical tools are Pangas (machetes) and axes for cutting wood; and spades, rakes, and Jembes (hoes) for preparing and tending kilns. Some tools are owned, and others are borrowed from neighbors, occasionally for at small fee. In addition, the production process consumes grass, sand, animal dung for kiln preparation, and empty bags for packaging.

The main input factor is the work hours and knowledge. The production is laborintensive (Table 4, Figure 4). Half of the respondents obtain help from family members for cutting wood and carbonizing the wood: "We are two people who cut the trees and five people who arrange the logs/grass and set up the kiln" (female producer, Kwale). Others work on their own: "I do the work alone, nobody in the family can afford to help me because such work is so difficult" (female producer, Taita Taveta). During the rainy season, many producers must divide their time between charcoal production and tasks in their farms or halt charcoal production altogether.

Table 4. Worktime per run of seven bags.

\begin{tabular}{lr}
\hline Task & Work Hours \\
\hline Planning and selecting sites & 4.0 \\
Cutting and preparing pieces & 29.4 \\
Cutting grass & 4.2 \\
Staking & 2.1 \\
Digging soil to cover wood & 5.6 \\
Carbonization (monitoring) & 12.0 \\
Cooling and removing charcoal & 2.1 \\
Packaging and selling & 4.2 \\
Total work hours per run & 63 \\
\hline Work hours per bag & 9 \\
Work hours per year & 2100 \\
\hline
\end{tabular}

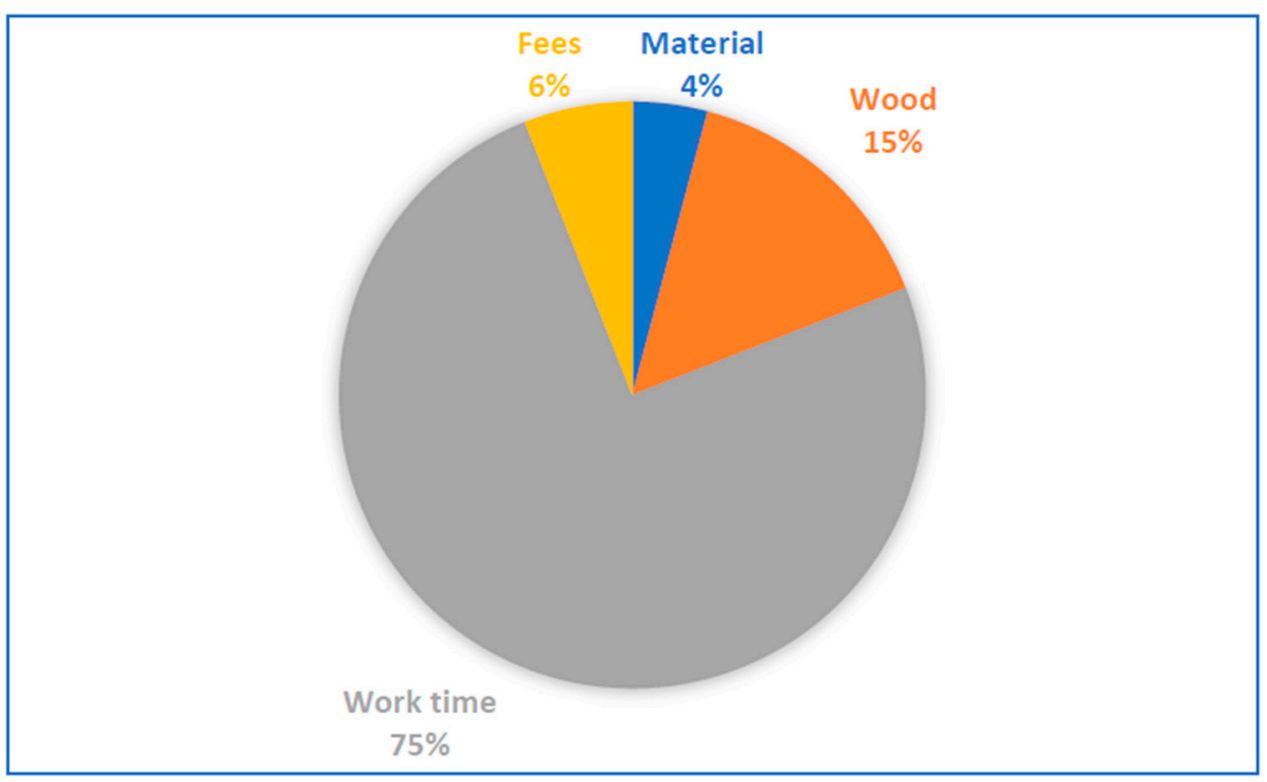

Figure 4. Cost shares for charcoal from producers.

Most of the work time is used for cutting and preparing wood for charcoal production. Carbonization requires 4-7 days and must be regularly monitored; in this calculation, it is 
assumed that this control could be conducted twice per day. Total work time for 33 runs over the year corresponds to 2100 working hours.

Financial investments are low and acquired from previous business earnings or credit from family members, lenders, or other credit facilities, such as microcredit facilities and Kenya Women Finance Trust.

While several charcoaling skills are crucial, they were often simply labeled by the respondents as traditional knowledge. When specified, these skills include physical strength, trees' harvesting skills, expertise in charcoal kiln preparation and monitoring, and knowledge of how to properly package the charcoal in the bags to avoid breakages. Most producers learned the profession from their parents, siblings, and/or neighbors, or simply by "observation". The respondents highlighted that the acquired skills and competencies contribute to increased safety, quality charcoal, efficiency in the production process, and better packaging. Almost $80 \%$ of the respondents have an educational level of primary school or higher. Both literacy and calculation skills were confirmed as useful in the trade for note-taking and for calculating revenues and costs.

\section{Partners}

Charcoal production is mainly an individual or family business. However, neighbors and friends cooperate and exchange knowledge and skills. Actors in the value chain-the transporters, customers, and middlemen—represent key market information sources. Other partners or stakeholders included projects by non-governmental organizations (NGOs), such as Wildlife Works, or extension projects. Before the charcoal ban was introduced, CPAs were organizing producers to coordinate sales and reforestation; after the charcoal ban in 2018, however, CPAs have lost most of their formal role and authority, and are much weakened, with some even dissolving.

The World Wildlife Fund (WWF) has supported the development of wood-fuel regulations in the counties of Kwale and Kilifi, the branding and certification of locally produced forest products, and capacity building to establish community cooperatives for marketing nature-based forest products.

The respective county governments and the Kenya Forest Service (KFS) are supervising the use of forest resources. Charcoal producers complain of corruption and confiscation of charcoal volumes while in transit.

\subsubsection{Economic Value Capture: Costs and Revenues}

The average price of charcoal per bag of approximately $40 \mathrm{~kg}$ was USD 6.66. Charcoal producers using trees from ranches make in-kind payment for green wood with a share of the charcoal, or with a fee per bag produced. The costs for tools for tree felling and operations of the kiln are shown in Table 5.

Table 5. Price per tool or material.

\begin{tabular}{lr}
\hline Tool/Material & Price/Unit, USD \\
\hline Panga (machete) & 2.8 \\
Axe & 5.5 \\
Spade (shovel) & 4.6 \\
Bucket & 1.8 \\
Jembe (hoe) & 4.6 \\
Empty bag & 0.23 \\
\hline
\end{tabular}

The annual income statement from a typical production of charcoal is shown in Table 6. Input variables are based on charcoal prices at the production site, costs for wood, tools, and empty bags for packaging the charcoal (Table 5), estimated fees and taxes, and work hours required for charcoal production (Table 4). The calculation does not consider transport to the kiln site, risk factors, work-related injuries, and price reductions explained by quality problems. 
Table 6. Income statement, annual.

\begin{tabular}{lr}
\hline Items & USD \\
\hline Operating revenues (USD 6.66/bag $\times 231$ & 1531 \\
bags) & 231 \\
Wood cost, (USD 1/bag $\times 231$ bags) & 6 \\
Tool expense * & 57 \\
Empty bags & 92 \\
Fees $* *$ & 1154 \\
Net income & 0.55 \\
Net income per work hour & 0.92 \\
Daily income per family member ${ }^{* * *}$ & \\
\hline Production: 7 bags/run, 33 runs/year, 231 bags/year. ${ }^{*}$ Panga, jembe, spade, and axe, estimated lifetime = 3 years.
\end{tabular}

Table 6 shows that, based on a family with five children, the net income for the typical charcoal producer does not reach the poverty limit of USD 1.9/day and person, however, it achieves about half of this expectation, thereby underlining the important role charcoal play in poverty reduction. The household may also earn some additional income from agricultural production or other employment, mainly casual labor. The calculation presented in Table 6 is, on the other hand, based on full-time work, which does not provide for considerable time for additional income-generating activities.

Labor costs dominated elemental cost shares in charcoal production despite low hourly compensation (Table 6 and Figure 4). The cost of goods sold, that is, wood material, occupies a smaller cost share, and expenses (tools, empty bags) and fees represent less than $10 \%$ of the producer price. Before the charcoal ban, fees consisted of payments to the CPA and transportation/movement permits.

\subsubsection{Sensitivity Analysis: Costs and Incomes}

To illustrate the business model and its opportunities for improved economic value, economic capture scenarios were calculated based on responses to questions regarding charcoaling-process risks, quality problems, and unexpected costs.

- Large kiln: Increased production was reported as a method to increase profits. In this scenario, we assume an increase from 7 to 10 bags/run. Revenues proportionally increased with economies of scale in the production assumed.

- Increased quality: Skills in kiln management were frequently emphasized by respondents. Quality management was assumed to increase the average unit charcoal price by $10 \%$.

- Kiln breakage: The kiln opens up, allowing air to enter the kiln leading to accelerated wood combustion that leads to lower charcoal yields. In this scenario, it was assumed that $10 \%$ of the runs were lost for this reason or two runs per year.

In all other aspects, the conditions would be the same as those in a typical enterprise, as described in Table 6. Net income per work hour are shown in Figure 5 and compared with the original figures for business as usual (BAU).

Figure 5 shows that a large kiln could increase income per hour by $6 \%$. However, the time for wood harvesting and preparation also increases, which leads to more working hours and probably the need to engage one more family member in the production. Higher average quality would improve hourly income by $13 \%$ whereas increased risk for accidents reduces income per hour by $7 \%$. Findings highlight various short-run aspects that influence profit margins and household incomes. It is likely that modest income improvements for poor households, such as quality improvement, have a significant impact on the household's living conditions. 


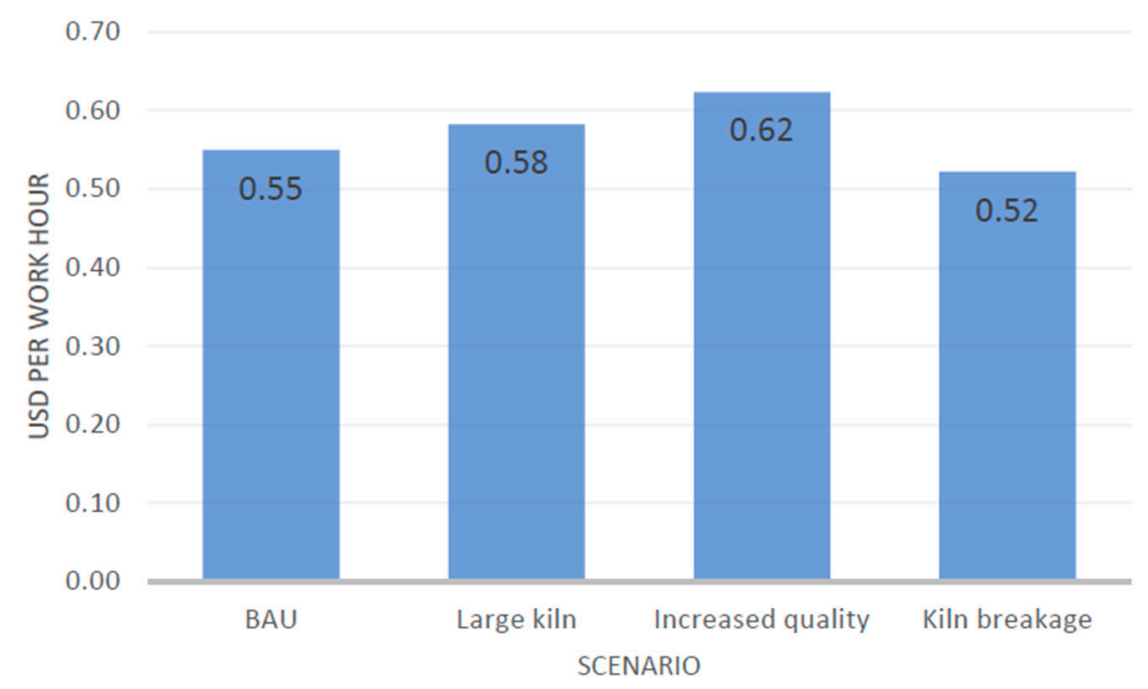

Figure 5. Economic scenarios: Increased production, improved quality, kiln breakages.

\subsubsection{Sustainability Impact}

Interviews and group discussions revealed that charcoal production affects different sustainability indicators. Table 7 presents impacts that were reported by the majority of the respondents.

Table 7. Impact of charcoal business on SDGs (Direction of impact is provided in brackets).

\begin{tabular}{ll}
\hline SDG (Shortened) & Impact from Charcoal Production \\
\hline Goal 1. End poverty. & $\begin{array}{l}\text { Charcoal income reduces poverty, but may not } \\
\text { lift households above the poverty line. Income } \\
\text { is reported as used for basic needs (+). }\end{array}$ \\
Goal 2. End hunger, achieve food security. & $\begin{array}{l}\text { Charcoal income is used to buy food (+). } \\
\text { Charcoal income pays for children's education. } \\
\text { Goal 4. Ensure inclusive and equitable quality } \\
\text { education. }\end{array}$ \\
$\begin{array}{l}\text { Parents have to buy uniforms, learning } \\
\text { materials, and books at the primary level. }\end{array}$ \\
$\begin{array}{l}\text { Secondary-school fees are partly } \\
\text { government-subsidized, but parents pay a part } \\
\text { and for books and lunch (+). }\end{array}$ \\
$\begin{array}{l}\text { If based on unsustainable forest management } \\
\text { practices, charcoal production degrades forests } \\
\text { Goal 15. Protect, restore, and promote life on }\end{array}$ \\
\hline land (forests).
\end{tabular}

(+), positive impact; $(-)$, negative impact.

The main positive impacts include the livelihood contribution of the charcoal income, which reduced but did not eliminate poverty. Proceeds are used for basic needs, including school fees. In addition to the main impacts in Table 7, there are other income-related co-benefits associated with charcoal production, which have an indirect impact on some SDGs. These benefits include affordable reliable energy though not clean; and income used to meet health and house construction expenses. Further, these constitute a critical income source for women, including single women with children. These co-benefits could indirectly contribute to the achievement of respective SDGs. On the negative side, charcoal producers reported that an intensified charcoal production, together with farmland expansion, contributes to forest loss. However, before the charcoal ban, CPAs used to undertake reforestation and afforestation activities on degraded forests and land, in line with the developed conservation plans for their areas of operations. These activities stopped with the charcoal ban. 


\subsubsection{Sustainability Feedback Impact}

The last component of the SDGs summarizes how the status the SDGs in the country or region influence on the charcoal enterprises' profitability and long-term viability.

Table 8 presents mixed such feedback impacts of SDG status on charcoal businesses. Respondents reported that acquired reading and writing skills helped them in carrying out the charcoal business. However, the business was also affected by a decreasing supply of quality tree species for charcoal production and long distances to the wood sources. The current charcoal ban was viewed as ineffective since charcoal trade continues in different forms, counterproductive, and unfair, which relates well to SDG target 17.14 that describes policy coherence in terms of how policies are coordinated. With respect to co-benefits, it was also possible to identify several SDG indicators with an indirect feedback impact on the business prospects, that is, the nutrition, general health situation, and women equality.

Table 8. Feedback impact of SDG status on charcoal business (Direction of impact is provided in brackets).

\begin{tabular}{|c|c|}
\hline SDG (Shortened) & Feedback on Charcoal Production \\
\hline $\begin{array}{l}\text { Goal 4. Ensure inclusive and equitable quality } \\
\text { education. }\end{array}$ & $\begin{array}{l}\text { Producers with primary education use reading } \\
\text { and numeric skills in their business operations. } \\
\text { However, they need additional planning and } \\
\text { production skills (+). }\end{array}$ \\
\hline Goal 8. Decent work and economic growth" & $\begin{array}{l}\text { High unemployment levels push rural } \\
\text { community members with low literacy levels } \\
\text { to resort to charcoal enterprises for survival. } \\
\text { This increases competition, reduces profit } \\
\text { margins, and accelerates forest degradation (-). }\end{array}$ \\
\hline $\begin{array}{l}\text { Goal 15. Protect, restore, and promote life on } \\
\text { land (forests). }\end{array}$ & $\begin{array}{l}\text { The charcoaling industry is affected by forest } \\
\text { loss and degradation caused by farmland } \\
\text { expansion and charcoal production as well as } \\
\text { restricted access to forest resources such as } \\
\text { during ban (-). }\end{array}$ \\
\hline $\begin{array}{l}\text { Goal 17. Strengthen means of implementation } \\
\text { and revitalize Global Partnership for }\end{array}$ & Complaints about allegedly misdirected \\
\hline Sustainable Development (Policy Coherence) & sympathize with the reduced role of CPAs $(-)$. \\
\hline
\end{tabular}
(+), positive impact; (-), negative impact.

\subsection{Synthesizing SBM for a Charcoal Business}

A synthesized SBM of an informal charcoal producer, according to Figure 1, describes the business components and their linkages to sustainability goals. It represents a dual interaction between the business activity and sustainability and impacts and feedback impacts with positive and negative signs. The model and its empirical application do not highlight an "optimal" SBM; it is even likely that such an ultimate model is not available. However, it identifies the key interactions that affect sustainability.

\section{Discussion}

This analysis found that producers apply consistent business models for their operations. The value proposition emphasizes the quality dimension, which can be upheld by the choice of tree species and the management of the process. Marketing skills and service quality dimensions are also important. Value creation steps encompass activities where both tangible and intangible resources are employed and combined. Raw wood material and labor are the main inputs, and producers put effort into strategic planning and deploying skills to optimize the production processes for the best efficiency and quality. The economic calculations highlight the key characteristics of value capture: low entry barriers, high labor intensity, and low profit margins.

The findings show that the charcoal producers, in some aspects, are acting strategically in conceiving and implementing their business plans. They also apply a reasonable market 
analysis that takes into account the operational aspect and institutional and economic factors. However, constraints associated with low inputs, education level, short-term needs, and poverty constrain producers from making long-term plans. Variable policies, including recurring charcoal bans, could add to the insecurity of such businesses and their long term viability. The increasing unrestrained demand for charcoal (there are no laws against charcoal consumption/use) by all segments of the society has meant that charcoal production remains a continued reality.

This study is novel by developing and using a framework for SBM analysis among informal charcoal enterprises in Kenya. SBMs have rarely been discussed for informal enterprises such as charcoal producers. The application of the model on charcoal-producing enterprises in Kenya generated insights on mixed linkages between charcoal production and some SDGs.

Enterprises face a harsh business reality with few real options. Profits can be improved by increasing production through larger kilns that increases turnover, enhances quality, or reduces accidents or kiln breakages that cause injuries and economic loss. Higher profits will, in turn, support the achievement of some SDGs by, for example, reducing (if not eliminating) poverty, improving access to housing and health, and financing school fees. A sustainability transition implies, however, that these benefits are supported by sustainable forest management practices (sustainability feedback), and by coherent enabling policies that support an efficient and sustainable charcoal production.

Several aspects of the livelihoods and poverty aspects of charcoal production are recognized from other studies from various African countries $[10,11,15]$. These analyses also found that charcoal contributes to covering basic livelihood needs. The key role for feedback impacts from policy and sustainable forestry conform with findings in previous related studies [14].

However, this study also suggest an important field for the application and development of SBMs: informal biobased enterprises. The charcoal sector is still key for low-income households, and hence measures to regulate it should consider the poor rural households that depend on it to support their livelihoods. The analysis of the wide range of sustainability impacts is therefore relevant. The findings present evidence to inform policymakers to support the charcoal enterprises and thus emphasize their potential to contribute towards achieving some SDGs.

The SBM analyses highlight measures to guide a sustainability transition in the charcoal sector. Livelihood improvements should be achieved by introducing adoptable process enhancements that prevent accidents, and support quality management through improved charcoaling technologies, efficient kilns, and tree species selection. Tree species such as Acacia spectabilis, Sesbania sesban, Acacia polyacantha, and Acacia xanthophloea that coppice after harvesting and grow very fast could be prioritized for charcoaling to ensure a sustainability transition in the charcoal sector. These species are leguminous and fix nitrogen to the soil, thereby improving fertility - a key ingredient in supporting agricultural production that provides supplementary income to that from charcoal. Notably, coppicing and fast growth attributes of the species could secure a sustainable supply of the materials for quality charcoal production. The acquisition of better planning and management skills and enhanced collaboration that fosters knowledge transfer and strengthens producers' bargaining power with traders and transporters may also increase incomes and consequently the impact on some SDG indicators. Halting the ongoing forest degradation and achieving a community-based sustainable forest management regime are critical issues for any successful long-term business model.

Creating alternative income sources, improving education status, and developing appropriate policies that could regulate sustainable forest management and the charcoal sector are other interventions that improve sustainability status in relation to both livelihoods and forest conservation. The model, furthermore, suggests that subsidized schooling could reduce the need for monetary income for school fees, and consequently marginally reduce the incentives to engage in charcoal production for these reasons. 
The analysis presented above has limitations. The empirical results are specific for the location, and the charcoal industry structure is likely to vary between locations in Africa. Any generalization must, therefore, be done with much caution. However, the study's aim was explorative and it is possible that similarities exist across the continent since the occupation generally employs low-income people in small-scale enterprises. Furthermore, this study did not analyze how income from charcoal complements other household income sources [41]. It focused on a specific activity and industry: charcoal production. Notably, the SBM cannot solve all sustainability issues associated with charcoal production. One key issue is the association of charcoal with indoor pollution at the consumer level. However, the SBM approach can be useful for comparisons of different biobased energy sources such as pellets and biochar among others, as well as for improved cooking stoves.

Extended analyses could incorporate the health impact of charcoal at the user stage [1] (p. 73), which is not covered in depth in this study. Fuelwood and charcoal combustion creates indoor air pollution with health consequences [42]. Efforts have been made to promote cleaner cooking alternatives, with often limited or mixed results $[43,44]$. Possibly charcoal in the future can be replaced by cleaner cooking methods and rural livelihoods may also be supported by other activities. However, considering the size and trend of charcoal production, regulations may be warranted in the short- and medium-term that can integrate business and sustainability goals. One such approach in this process could be to analyze the sector in its context and seek sustainable solutions that make business sense for the stakeholders.

\section{Conclusions}

The business model canvas and our SBM qualitatively outlined the strategic situation for charcoal producers that integrates sustainability linkages; hence, it does not present a template SBM but shows the key influencing factors.

This study on business models and sustainability connections contributes to the growing literature on SBMs. Using charcoal production and trade as an example, it highlighted the business aspect of informal rural production systems, showing that these systems, like other businesses, handle various challenges to generate value. Understanding the business model, combined with insights about institutions, culture, gender relations, and operational conditions, helps to analyze and identify ways for charcoal producers in Kenya to attain better and more sustainable livelihoods.

Author Contributions: D.M. (Conceptualization, Methodology, Formal analysis, Investigation, Writing, Funding acquisition); L.M. (Conceptualization, Methodology, Formal analysis, Investigation, Writing, Funding acquisition); C.W. (Methodology, Formal analysis, Investigation, Writing); G.K. (Conceptualization, Methodology, Writing, Funding acquisition); A.R. (Conceptualization, Methodology, Formal analysis, Investigation, Writing, Funding acquisition). All authors have read and agreed to the published version of the manuscript.

Funding: This work was supported by the FORMAS, the Swedish government research council for sustainable development (No. 2017-00210).

Institutional Review Board Statement: Not applicable.

Informed Consent Statement: Informed consent was obtained from all subjects involved in the study.

Data Availability Statement: The data presented in this study are available on request from the corresponding author.

Acknowledgments: The authors wish to thank charcoal value chain actors in Kwale and Taita Taveta counties for their participation and contribution with ideas and analysis. We are also grateful to the dedicated enumerators in Kwale and Taita Taveta counties who carried out the interviews. The constructive suggestions by three anonymous reviewers are gratefully acknowledged. The authors also received valuable comments from Björn Lundgren. 
Conflicts of Interest: The authors declare no conflict of interest. The funders had no role in the design of the study; in the collection, analyses, or interpretation of data; in the writing of the manuscript, or in the decision to publish the results.

\section{Appendix A}

Enterprise Levels

Although the synthesized model above describes the typical traits of informal enterprises, the business model is conceived, implicitly or explicitly, for the individual enterprise based on its resources and goals [25]. The SBM was consequently applied to six example charcoal enterprises to illustrate commonalities in differences between SBM contents. The business units are all own account enterprises. Business model components, and their sustainability implications, are shown in Table A1.

Table A1. Business models, informal charcoal producers.

\begin{tabular}{|c|c|c|c|c|c|c|}
\hline & \multicolumn{6}{|c|}{ Charcoal Producer } \\
\hline & $\mathbf{A}$ & B & $\mathrm{C}$ & $\mathbf{D}$ & $\mathbf{E}$ & $\mathbf{F}$ \\
\hline $\begin{array}{l}\text { Respondent } \\
\text { and household }\end{array}$ & $\begin{array}{l}\text { Female, } 29 \text { yrs } \\
\text { married } \\
\text { no schooling } \\
6 \text { children }\end{array}$ & $\begin{array}{l}\text { Female } 41 \text { yrs } \\
\text { married } \\
\text { primary school } \\
3 \text { children }\end{array}$ & $\begin{array}{l}\text { Female } 33 \text { yrs } \\
\text { married } \\
\text { primary school } \\
6 \text { children }\end{array}$ & $\begin{array}{l}\text { Male } 60 \text { yrs } \\
\text { widower } \\
\text { primary school } \\
10 \text { children }\end{array}$ & $\begin{array}{l}\text { Male } 35 \text { yrs } \\
\text { married } \\
\text { primary school } \\
2 \text { children }\end{array}$ & $\begin{array}{l}\text { Male } 45 \text { yrs } \\
\text { married, } \\
\text { primary school, } \\
3 \text { children }\end{array}$ \\
\hline $\begin{array}{l}\text { Other income if } \\
\text { charcoal } \\
\text { production was } \\
\text { not possible }\end{array}$ & Farming & $\begin{array}{l}\text { Building houses } \\
\text { and farming }\end{array}$ & $\begin{array}{l}\text { Farming and } \\
\text { being a } \\
\text { househelp }\end{array}$ & $\begin{array}{l}\text { Self-employed } \\
\text { and farming }\end{array}$ & $\begin{array}{l}\text { Farming and } \\
\text { having cattle }\end{array}$ & Casual labor \\
\hline Bags/year & 78 & 144 & 210 & 120 & 204 & 480 \\
\hline $\begin{array}{l}\text { Value } \\
\text { proposition }\end{array}$ & $\begin{array}{l}\text { Quality to } \\
\text { returning } \\
\text { customers }\end{array}$ & $\begin{array}{l}\text { Quality, good } \\
\text { service, home } \\
\text { delivery, } \\
\text { politeness }\end{array}$ & $\begin{array}{l}\text { Quality to } \\
\text { returning } \\
\text { customers }\end{array}$ & $\begin{array}{l}\text { Quality to } \\
\text { returning and } \\
\text { spot customers }\end{array}$ & $\begin{array}{l}\text { Quality and } \\
\text { availability to } \\
\text { returning } \\
\text { customers }\end{array}$ & $\begin{array}{l}\text { Quality and } \\
\text { availability to } \\
\text { returning } \\
\text { customers }\end{array}$ \\
\hline $\begin{array}{l}\text { Challenges/ } \\
\text { Unexpected } \\
\text { costs }\end{array}$ & $\begin{array}{l}\text { Variable prices } \\
\text { Reducing wood } \\
\text { supply } \\
\text { Middlemen } \\
\text { capture margin. }\end{array}$ & $\begin{array}{l}\text { Customers lack } \\
\text { money } \\
\text { Reduced } \\
\text { supply of } \\
\text { quality wood } \\
\text { Wild animals } \\
\text { Bags get torn }\end{array}$ & $\begin{array}{l}\text { Charcoal } \\
\text { production in } \\
\text { rainy season is } \\
\text { hard } \\
\text { Working } \\
\text { conditions are } \\
\text { challenging }\end{array}$ & $\begin{array}{l}\text { Burning during } \\
\text { heavy winds } \\
\text { Charcoal ban } \\
\text { Lack of mature } \\
\text { trees } \\
\text { Kiln breakage }\end{array}$ & $\begin{array}{l}\text { Charcoal ban } \\
\text { Working } \\
\text { conditions }\end{array}$ & $\begin{array}{l}\text { Fatigue } \\
\text { Kiln breakage }\end{array}$ \\
\hline Use of income & $\begin{array}{l}\text { school fees, } \\
\text { food, clothing }\end{array}$ & $\begin{array}{l}\text { school fees, } \\
\text { food, clothing }\end{array}$ & $\begin{array}{l}\text { school fees, } \\
\text { food, and } \\
\text { clothes }\end{array}$ & $\begin{array}{l}\text { school fees, } \\
\text { food, clothing, } \\
\text { savings, } \\
\text { healthcare }\end{array}$ & $\begin{array}{l}\text { school fees, } \\
\text { food, clothing }\end{array}$ & $\begin{array}{l}\text { school fees, } \\
\text { food, clothing }\end{array}$ \\
\hline Plans & $\begin{array}{l}\text { Wish to } \\
\text { increase } \\
\text { production }\end{array}$ & & & & & $\begin{array}{l}\text { Increase } \\
\text { production } \\
\text { Start transport } \\
\text { of charcoal }\end{array}$ \\
\hline
\end{tabular}

Table A1 shows similarities between the producers concerning the value proposition including quality parameters and market segments. The key components of the value creation are also similar between the enterprises. The technology is basic, while the amount spent on tools and equipment is low. The aspirations to improve revenues include an increased turnover/productivity. In one case, F, transport to a population center was considered as an approach to improve the profit margin.

\section{References}

1. FAO. The Charcoal Transition: Greening the Charcoal Value Chain to Mitigate Climate Change and Improve Local Livelihoods; van Dam, J., Ed.; Food and Agriculture Organization of the United Nations: Rome, Italy, 2017.

2. FAO. FAOSTAT. 2020. Available online: http://www.fao.org/faostat/en/\#data/FO (accessed on 9 March 2021). 
3. FAO. Sustainable Charcoal Production; African Wildlife and Forestry Commission, 2020. Available online: http://www.fao.org/3/ ca7967en/ca7967en.pdf (accessed on 18 March 2021).

4. United Nations. Transforming Our World: The 2030 Agenda for Sustainable Development; UN Publishing: New York, NY, USA, 2015.

5. FAO. State of the World's Forests Enhancing the Socioeconomic Benefits from Forests; Food and Agriculture Organization of the United Nations: Rome, Italy, 2014.

6. Kiruki, H.M.; van der Zanden, E.H.; Malek, Ž.; Verburg, P.H. Land Cover Change and Woodland Degradation in a Charcoal Producing Semi-Arid Area in Kenya. Land Degrad. Dev. 2017, 28, 472-481. [CrossRef]

7. Chiteculo, V.; Lojka, B.; Surový, P.; Verner, V.; Panagiotidis, D.; Woitsch, J. Value Chain of Charcoal Production and Implications for Forest Degradation: Case Study of Bié Province, Angola. Environments 2018, 5, 113. [CrossRef]

8. Nerini, F.F.; Tomei, J.; To, L.S.; Bisaga, I.; Parikh, P.; Black, M.; Borrion, A.; Spataru, C.; Broto, V.C.; Anandarajah, G.; et al. Mapping synergies and trade-offs between energy and the Sustainable Development Goals. Nat. Energy 2018, 3, 10-15. [CrossRef]

9. Nilsson, M.; Chisholm, E.; Griggs, D.; Howden-Chapman, P.; McCollum, D.; Messerli, P.; Neumann, B.; Stevance, A.S.; Visbeck, M.; Stafford-Smith, M. Mapping interactions between the sustainable development goals: Lessons learned and ways forward. Sustain. Sci. 2018, 13, 1489-1503. [CrossRef] [PubMed]

10. Zulu, L.C.; Richardson, R.B. Charcoal, livelihoods, and poverty reduction: Evidence from sub-Saharan Africa. Energy Sustain. Dev. 2013, 17, 127-137. [CrossRef]

11. Smith, H.E.; Hudson, M.D.; Schreckenberg, K. Livelihood diversification: The role of charcoal production in southern Malawi. Energy Sustai. Dev. 2017, 36, 22-36. [CrossRef]

12. Schure, J.; Levang, P.; Wiersum, K.F. Producing Woodfuel for Urban Centers in the Democratic Republic of Congo: A Path Out of Poverty for Rural Households? World Dev. 2014, 64, S80-S90. [CrossRef]

13. Smith, H.E.; Eigenbrod, F.; Kafumbata, D.; Hudson, M.D.; Schreckenberg, K. Criminals by necessity: The risky life of charcoal transporters in Malawi. For. Trees Livelihoods 2015, 24, 259-274. [CrossRef]

14. Doggart, N.; Meshack, C. The Marginalization of Sustainable Charcoal Production in the Policies of a Modernizing African Nation. Front. Environ. Sci. 2017, 5, 27. [CrossRef]

15. Zorilla-Miras, P.; Mahamane, M.; Metzger, M.J.; Baumert, S.; Vollmer, F.; Luz, A.C.; Woollen, E.; Sitoe, A.A.; Patenaude, G.; Nhantumbo, I.; et al. Environmental Conservation and Social Benefits of Charcoal Production in Mozambique. Ecol. Econ. 2018, 144, 100-111. [CrossRef]

16. Geissdoerfer, M.; Vladimirova, D.; Evans, S. Sustainable business model innovation: A review. J. Clean. Prod. 2018, 198, 401-416. [CrossRef]

17. França, C.L.; Broman, G.; Robèrt, K.-H.; Basile, G.; Trygg, L. An approach to business model innovation and design for strategic sustainable development. J. Clean. Prod. 2017, 140, 155-166. [CrossRef]

18. Ludeke-Freund, F.; Carroux, S.; Joyce, A.; Massa, L.; Breuer, H. The sustainable business model pattern taxonomy-45 patterns to support sustainability-oriented business model innovation. Sustain. Prod. Consum. 2018, 15, 145-162. [CrossRef]

19. World Bank. World Development Indicators. Available online: https://datatopics.worldbank.org/sdgs/ (accessed on 9 March 2021).

20. FAO. Global Forest Resources Assessment 2020: Main Report; Food and Agriculture Organization of the United Nations: Rome, Italy, 2020.

21. ILO. Women and Men in the Informal Economy: A Statistical Picture, 3rd ed.; International Labour Office: Geneva, Switzerland, 2018.

22. Goyal, S.; Sergi, B.S.; Kapoor, A. Understanding the key characteristics of an embedded business model for the base of the pyramid markets. Econ. Sociol. 2014, 7, 26. [CrossRef] [PubMed]

23. Edmondson, D.L.; Kern, F.; Rogge, K.S. The co-evolution of policy mixes and socio-technical systems: Towards a conceptual framework of policy mix feedback in sustainability transitions. Res. Policy 2019, 48, 103555. [CrossRef]

24. Osterwalder, A.; Pigneur, Y. Clarifying business models: Origins, Present, and future of the concept. Commun. AIS 2005, 16. [CrossRef]

25. Baldassarre, B.; Keskin, D.; Diehl, J.C.; Bocken, N.; Calabretta, G. Implementing sustainable design theory in business practice: A call to action. J. Clean. Prod. 2020, 273. [CrossRef]

26. Joyce, A.; Paquin, R.L. The triple layered business model canvas: A tool to design more sustainable business models. J. Clean. Prod. 2016, 135, 1474-1486. [CrossRef]

27. Republic of Kenya. County Government of Kwale. First County Integrated Development Plan. 2013. Available online: http:/ / www.kpda.or.ke/documents/CIDP/Kwale.pdf (accessed on 9 March 2021).

28. Republic of Kenya. County Government of Taita-Taveta. County Integrated Development Plan 2018-2022. Available online: https: / / www.cog.go.ke/cog-reports/category/106-county-integrated-development-plans-2018-2022?download=307:taitataveta-county-integrated-development-plan-2018-2022 (accessed on 9 March 2021).

29. Republic of Kenya. County Government of Mombasa. Second County Development Plan 2018-2022. Available online: https: / / kecosce.org/ county-government-of-mombasa-second-county-integrated-development-plan-2018-2022/ (accessed on 9 March 2021).

30. KNBS. Kenya Population and Housing Census. Volume III: Distribution of Population by Age and Sex; Kenya National Bureau of Statistics: Nairobi, Kenya, 2019. Available online: https: / /www.knbs.or.ke/?wpdmpro=2019-kenya-population-and-housingcensus-volume-iii-distribution-of-population-by-age-sex-and-administrative-units (accessed on 9 March 2021). 
31. Republic of Kenya. The Kenya Gazette Vol. CXX, No. 28, 26 February 2018; Republic of Kenya: Nairobi, Kenya, 2018.

32. Ndegwa, G.; Sola, P.; Iiyama, M.; Okeyo, I.; Njenga, M.; Siko, I.; Muriuki, J. Charcoal Value Chains in Kenya: A 20-Year Synthesis; Working Paper No. 307; World Agroforestry Center: Nairobi, Kenya, 2020.

33. Yin, R.K. Case Study Research-Design and Methods, 5th ed.; SAGE Publications: Los Angeles, CA, USA, 2014.

34. Miles, M.B.; Huberman, A.M. Qualitative Data Analysis-An Expanded Sourcebook; SAGE Publications: Los Angeles, CA, USA, 1994.

35. Mikkelsen, B. Methods for Development Work and Research-A New Guide for Practitioners; SAGE Publications: Los Angeles, CA, USA, 2005.

36. Grant, R.E. Contemporary Strategy Analysis; John Wiley Sons Inc.: Hoboken, NJ, USA, 2015.

37. Pain, R.; Francis, P. Reflections on participatory research. Area 2003, 35, 46-54. [CrossRef]

38. International Society of Ethnobiology. International Society of Ethnobiology Code of Ethics. 2006. Available online: http: / / ethnobiology.net/ code-of-ethics/ (accessed on 6 March 2021).

39. Berk, J.; DeMarzo, P. Corporate Finance, 5th ed.; Pearson: Harlow, UK, 2020.

40. OECD. What Are Equivalence Scales? 2020. Available online: http://www.oecd.org/economy/growth/OECD-NoteEquivalenceScales.pdf (accessed on 9 March 2021).

41. Ellis, F. The determinants of rural livelihood diversification in developing countries. J. Agric. Econ. 2000, 51, 289-302. [CrossRef]

42. Gordon, S.B.; Bruce, N.G.; Grigg, J.; Hibberd, P.L.; Kurmi, O.P.; Lam, K.-B.H.; Mortimer, K.; Asante, K.P.; Balakrishnan, K.; Balmes, J.; et al. Respiratory risks from household air pollution in low and middle income countries. Lancet Respir. Med. 2014, 2, 823-860. [CrossRef]

43. Kshirsagar, M.P.; Kalamkar, V.R. A comprehensive review on biomass cookstoves and a systematic approach for modern cookstove design. Renew. Sustain. Energy Rev. 2014, 30, 580-603. [CrossRef]

44. Mehetre, S.A.; Panwar, N.L.; Sharma, D.; Kumar, H. Improved biomass cookstoves for sustainable development: A review. Renew. Sustain. Energy Rev 2017, 73, 672-687. [CrossRef] 